\title{
Clarifying the relationship between pulmonary langerhans cell histiocytosis and Alpha 1 antitrypsin deficiency
}

\author{
Cormac McCarthy ${ }^{1,2}$, Emmanuelle Bugnet ${ }^{3}$, Amira Benattia ${ }^{3}$, Michael P. Keane ${ }^{1,2}$, Benoit Vedie ${ }^{4}$, \\ Gwenaël Lorillon ${ }^{3}$ and Abdellatif Tazi ${ }^{3,5,6^{*}}$ (I)
}

\begin{abstract}
Pulmonary Langerhans cell histiocytosis (PLCH) is a rare, smoking related, progressive diffuse cystic lung disease that occurs primarily in smokers. The aim of this study was to determine if there was an increase in alpha- 1 antitrypsin deficient alleles or phenotypes in a large series of PLCH patients and whether serum alpha- 1 antitrypsin levels correlated with markers of disease severity. Fifty PLCH patients, 24 with a diffuse cystic lung pattern and 26 with a typical nodulo-cystic pattern on imaging were included. The mean alpha-1 antitrypsin levels were in normal range for both the population with diffuse cystic lung pattern population $(1.39 \mathrm{~g} / \mathrm{L} \pm 0.37)$ and the nodulo-cystic pattern group $(1.41 \mathrm{~g} / \mathrm{L} \pm 0.21)$. Deficiency alleles PiZ and PiS were $1 \%$ and $2 \%$ respectively in the entire study population of 50 patients, demonstrating no increased incidence of alpha-1 antitrypsin deficiency in PLCH. Alpha-1 antitrypsin levels showed no correlation with lung function parameters or extent of cystic lesions on lung computed tomography.
\end{abstract}

\section{Main text}

Pulmonary Langerhans cell histiocytosis $(\mathrm{PLCH})$ is a rare, smoking related, progressive diffuse cystic lung disease that occurs mainly in young smokers of both genders [1]. In adults, it is frequently the only manifestation of the disease, but may also be a part of systemic disease [1]. Findings on high resolution computed tomography (HRCT) varies from a nodulo-cystic pattern in recently diagnosed PLCH to a diffuse cystic lung disease pattern $[2,3]$. In the latter, the disease may be misinterpreted as emphysema, and given the smoking history the diagnosis may be difficult to delineate. Furthermore, in long standing PLCH patients superimposed emphysema can be observed. Approximately $50 \%$ of PLCH patients harbour somatic $B R A F^{\mathrm{V} 600 \mathrm{E}}$ mutations in cells of the

\footnotetext{
*Correspondence: abdellatif.tazi@aphp.fr

${ }^{6}$ Centre National de Référence des Histiocytoses, Service de

Pneumologie, Hôpital Saint-Louis, 1 Avenue Claude Vellefaux, 75475 Paris Cedex 10, France

Full list of author information is available at the end of the article
}

myeloid/monocyte lineage, and while the pathogenesis of PLCH is not entirely understood, it is likely related to smoking induced injury and induced dendritic cell dysfunction [4] and airway inflammation [5]. Langerhans cells accumulate in bronchiolar airways with lymphocytes, macrophages, and eosinophils, thought to result in tissue destruction and remodelling and resultant cyst formation. It has been proposed that metalloproteinases produced by inflammatory cells may contribute to destruction of extracellular matrix, including matrix metalloproteinases (MMPs) [6].

Alpha-1 antitrypsin (AAT) deficiency (AATD) is an autosomal codominant condition characterised by low circulating levels of AAT protein, the archetypal serine protease inhibitor. The most common variants associated with disease are the Z (Glu342Lys) and S (Glu$264 \mathrm{Val}$ ) mutations, caused by the substitution of glutamic acid for lysine or valine at positions 342 and 264 of the polypeptide [7,8]. AATD results in an increased risk of emphysema at a young age and the risk is increased with original author(s) and the source, provide a link to the Creative Commons licence, and indicate if changes were made. The images or other third party material in this article are included in the article's Creative Commons licence, unless indicated otherwise in a credit line to the material. If material is not included in the article's Creative Commons licence and your intended use is not permitted by statutory regulation or exceeds the permitted use, you will need to obtain permission directly from the copyright holder. To view a copy of this licence, visit http://creativecommons.org/licenses/by/4.0/. The Creative Commons Public Domain Dedication waiver (http://creativeco mmons.org/publicdomain/zero/1.0/) applies to the data made available in this article, unless otherwise stated in a credit line to the data. 
concomitant smoking [9]. In AATD there is an imbalance between proteases and antiproteases in the lung and there is abnormal inflammatory response and evidence of increased pulmonary inflammation [10,11]. Serine proteases may result in tissue injury and smoking may increase the amount present in the lung [12]. Consequently, it has been hypothesized that there may be a link between PLCH and AATD through a common pathway of proteolytic damage, further augmented by smoking [13]. In a small study conducted on 34 patients with PLCH there was an increased frequency of deficient AATD alleles noted, PiZ and PiS accounting for 5.88\% and $2.94 \%$ of alleles [14]. To further clarify this proposed relationship, we sought to measure AAT levels and evaluate AAT phenotype in a large series of carefully classified PLCH patients, including both predominant diffuse cystic lung disease pattern and the nodulo-cystic pattern of PLCH.

\section{Methods}

Fifty patients with a diagnosis of PLCH attending the National Reference Centre for Histiocytoses, Paris, France were included following informed consent (registry number: CNIL 909207; CCTIRS 09.191). All patients had diagnosis confirmed by either histology or based on typical HRCT findings either alone or in association with characteristic extrapulmonary involvement (e.g., lytic bone lesion, diabetes insipidus) following the exclusion of alternative diagnoses [3]. HRCT images were analysed at window levels appropriate for the pulmonary parenchyma (widths of $-600-1600 \mathrm{HU}$ ) and the extent of the cystic lesions (including thick- and thin-walled cysts) was assessed as previously described [3]. Patients were classified into subgroups according to $\mathrm{CT}$ score values. For the whole lung, the maximum value of the cystic HRCT score was 24, with a total cystic lung score value greater than 12 denoting high (13-18) and very high (19-24) extent of cystic lung lesions respectively [3]. Lung volumes were evaluated by plethysmography, and forced expiratory volume in one second $\left(\mathrm{FEV}_{1}\right)$ and forced vital capacity (FVC) were determined by flow curve volume. Diffusing capacity of carbon monoxide $\left(\mathrm{D}_{\mathrm{LCO}}\right)$ was measured using the single-breath method. Obstruction was defined as a ratio of $\mathrm{FEV}_{1}$ to $\mathrm{FVC}<70 \%$, lung restriction was defined as a total lung capacity (TLC) $<80 \%$ of the predicted value, and air trapping was defined as a ratio of residual volume (RV) to TLC $>120 \%$ of the predicted value. Serum/plasma concentration of AAT was determined by nephelometric assay (Beckman-Coulter, IMMAGE 800) with reference values of $1.0-2.7 \mathrm{~g} / \mathrm{L}$ [15]. AAT phenotypes were assessed with Hydragel 18 A1AT Isofocusing kit on a Hydrasys System (Sebia) as previously described [16].

\section{Results}

Twenty-four PLCH patients with a diffuse cystic lung pattern on HRCT were evaluated for A1AT, consisting of 15 current and 9 ex-smokers; 13 females and 11 males; and 9 patients with multisystem LCH. The median time between PLCH diagnosis and AAT serum measurement and phenotype analysis was 1 year [IQR, 0; 10]. PLCH diagnosis was histologically confirmed in 13 (54\%) patients (lung $\mathrm{n}=6$, bone $\mathrm{n}=2$, skin $\mathrm{n}=4$, gut $\mathrm{n}=1$ ), the other 11 patients had either multisystem PLCH $(\mathrm{n}=3)$ or had typical bizarre cysts. The median HRCT cyst score was 20 [IQR, 16.5; 22], 17 patients $(71 \%)$ had airflow obstruction with a median $\mathrm{FEV}_{1} \%$ predicted of 58.5 [39.5-69.5]. Twenty-six additional PLCH patients (17 females, all current smokers) with a typical nodulocystic lung HRCT pattern were also evaluated for AAT levels and phenotype, with a median time between PLCH diagnosis and AAT assessment of 0 year [IQR, $0 ; 5]$ (Table 1). The mean AAT level in the diffuse cystic lung disease pattern population was $1.39 \mathrm{~g} / \mathrm{L}( \pm 0.37)$ and $1.41 \mathrm{~g} / \mathrm{L}( \pm 0.21)$ in the nodulo-cystic pattern group. One compound heterozygote PiSZ individual was identified with an AAT level of $0.54 \mathrm{~g} / \mathrm{L}$ and one PiMS phenotype identified in the diffuse cystic cohort and all patients in the nodulo-cystic disease were PiMM. Deficiency alleles $\mathrm{PiZ}$ and $\mathrm{PiS}$ were $1 \%$ and $2 \%$ respectively in the entire cohort, while the incidence of PiZ and PiS in the French population are estimated at $7.6 \%$ and $1.3 \%$ [17], demonstrating that there is no increased incidence of AATD in PLCH. There was no correlation between AAT levels and $\mathrm{FEV}_{1}\left(\mathrm{R}^{2}=0.02135, \mathrm{p}=0.4957\right), \mathrm{FVC}\left(\mathrm{R}^{2}=0.02930\right.$, $\mathrm{p}=0.4239), \mathrm{D}_{\mathrm{LCO}}\left(\mathrm{R}^{2}=0.09381, \mathrm{p}=0.1552\right)$ or $\mathrm{CT}$ cyst scores $\left(R^{2}=0.1225, p=0.093\right)$.

\section{Discussion}

It has been previously hypothesized that there may be a link between PLCH and AATD. This is possibly due to shared mechanisms of proteolytic tissue damage. Previously it has been proposed that proteases produced by inflammatory cells in the lungs of PLCH may contribute to extracellular matrix destruction [6], and the primary mechanism of emphysema in AATD is the unopposed proteolytic damage of proteases due to lack of AAT to counteract this. Moreover, AATD is an inflammatory condition due to the reduced AAT capacity to modulate inflammatory cytokines, and similarly PLCH is an inflammatory condition [5]. Finally, it is evident that smoking affects protease activity and can alter the funciton of AAT 12. Hence, it was hypothesised that these two conditions may share a common pathogenic mechanism. Prior smaller studies have indicated a possible clinical link between the two rare diseases, however, our report is the biggest study to date, and we have demonstrated 
Table 1 Characteristics of PLCH patients included in the study

\begin{tabular}{|c|c|c|}
\hline Characteristics & Diffuse cystic pattern $n=24$ & $\begin{array}{l}\text { Nodulo-cystic } \\
\text { pattern } n=26\end{array}$ \\
\hline Age, years, median, [IQR] & $40[31-46.75]$ & $45[34-47]$ \\
\hline Female sex, n (\%) & $13(54 \%)$ & $17(65 \%)$ \\
\hline Histological diagnosis & $13(54 \%)$ & $3(12 \%)$ \\
\hline Isolated PLCH, n (\%) & $15(62.5 \%)$ & $23(88 \%)$ \\
\hline MS LCH, n (\%) & $9(37.5 \%)$ & $3(12 \%)$ \\
\hline Time from PLCH diagnosis, years, median, [IQR] & $1[0-10]$ & $0[0-5]$ \\
\hline Smoker, n (\%) & $15(62.5 \%)$ & $24(92 \%)$ \\
\hline Ex-smoker & $9(37.5 \%)$ & $2(8 \%)$ \\
\hline Dyspnoea & $18(75 \%)$ & $16(62 \%)$ \\
\hline NYHA II/III/IV & $9 / 8 / 1$ & $14 / 2$ \\
\hline TLC, $\%$ of predicted & $104[92.75-123.75]$ & $105[95.25-123]$ \\
\hline FVC, $\%$ of predicted & $78[69.25-87.25]$ & $100[84.25-114]$ \\
\hline RV/TLC, \% of predicted & $148.5[118.5-166.75]$ & $111.5[103-132.5]$ \\
\hline $\mathrm{FEV}_{1}, \%$ of predicted & $58.5[39.5-69.5]$ & $86.5[76-100]$ \\
\hline $\mathrm{FEV}_{1} / \mathrm{FVC} \%$ & $66[48.25-72]$ & $77[69.25-80.75]$ \\
\hline $\mathrm{D}_{\mathrm{LCO},} \%$ of predicted, $n=23$ & $37[28-56]$ & $52[41-63]$ \\
\hline Restriction* (\%) & 0 & 0 \\
\hline Obstruction (\%) & $17(71 \%)$ & $7(27 \%)$ \\
\hline Air trapping (\%) & $17(71 \%)$ & $10(38 \%)$ \\
\hline CT cyst score, median, $[\mathrm{IQR}]$ & $20[16.5-22]$ & N/A \\
\hline Alpha-1 antitrypsin level (g/L) (mean, SD) & $1.39( \pm 0.37)$ & $1.41( \pm 0.21)$ \\
\hline PiM allele frequency & $94 \%$ & $100 \%$ \\
\hline PiS allele frequency & $4 \%$ & $0 \%$ \\
\hline $\mathrm{PiZ}$ allele frequency & $2 \%$ & $0 \%$ \\
\hline
\end{tabular}

* Restriction was defined as TLC $<80 \%$ of predicted; obstruction as FEV $1 / F V C<70 \%$ and air trapping as RV/TLC $>120 \%$ of predicted

$\mathrm{PLCH}$, pulmonary Langerhans cell histiocytosis; AAT, alpha-1 antitrypsin; IQR, interquartile range; NYHA New York heart association, MS multisystem; TLC total lung capacity; FVC forced vital capacity; RV residual volume; FEV 1 forced expiratory volume in $1 \mathrm{~s}$; $\mathrm{D}_{\text {Lco }}$ diffusing capacity of carbon monoxide; N/A, not applicable

no increased rate of AATD or AAT deficient alleles in a large PLCH series. The prior hypothesis is not supported by this larger dataset, and moreover there was a lack of correlation between AAT level and pulmonary function or CT scores in PLCH. While indeed an imbalance between protease and antiprotease activity could contribute to cyst development in PLCH, whether this is metalloproteinase or serine protease driven remains unknown, it is apparent that there is no clinical link between these two rare lung diseases. To determine whether smoking related changes in antiprotease function plays a role remains unclear in $\mathrm{PLCH}$. Further mechanistic studies may elucidate if there is any role of AAT protein either as an antiprotease or immune modulator in the pathogenesis of PLCH, but this seems unlikely to be a major player given the lack of correlation in this study.

\section{Abbreviations}

AAT: Alpha-1 antitrypsin; AATD: Alpha-1 antitrypsin deficiency; $D_{\text {LCO }}$ : Diffusing capacity of carbon monoxide; FEV $_{1}$ : Forced expiratory volume in $1 \mathrm{~s}$; FVC: Forced vital capacity; HRCT: High resolution computed tomography;
IQR: Interquartile range; MMPs: Matrix metalloproteinases; PLCH: Pulmonary Langerhans cell histiocytosis; TLC: Total lung capacity; RV: Residual volume.

\section{Acknowledgments}

None.

\section{Authors' contributions}

AT and CMcC had full access to all the data in the study and take the responsibility for the content of the manuscript, including the data and analysis. AT assume full responsibility for the integrity of the submission as a whole, from inception to published article. EB extracted the data from the database, contributed to analyses, revised the paper and approved the final version of the manuscript. AB collected clinical data, contributed to data analysis including radiological results, drafted the manuscript, and approved the final version. MK contributed to data analysis, helped revise the manuscript and approved the final version of the manuscript. BV performed AAT measurements and phenotyping, helped revise the manuscript and approved the final version of the manuscript. GL contributed to the data acquisition, helped revise the manuscript and approved the final version of the manuscript. All authors have agreed to be accountable for all aspects of the work in ensuring that questions related to the accuracy or integrity of any part of the work are appropriately investigated and resolved. All authors read and approved the final manuscript.

Funding

This study did not receive financial support. 


\section{Availability of data and materials}

The data supporting the results reported in the current study are available from the corresponding author upon request.

\section{Ethics approval and consent to participate}

The study was performed in accordance with the Helsinki Declaration and approved by the Institutional Review Board (registry number: CNIL 909207; CCTIRS 09.191). All patients provided written informed consent for the use of their medical reports for research.

\section{Consent for publication}

Not applicable.

\section{Competing interests}

Dr McCarthy has no conflicts of interest to declare. Dr Bugnet has no conflicts of interest to declare. Dr Benattia has no conflicts of interest to declare. Dr Keane has no conflicts of interest to declare. Dr Vedie has no conflicts of interest to declare. Dr Lorillon declares travel accommodations from Vitalaire. Dr Tazi declares speaker fees from Chiesi, BMS, and travel accommodations from Boehringer Ingelheim, Astrazeneca, Teva, Vitalaire.

\section{Author details}

${ }^{1}$ Department of Respiratory Medicine, St. Vincent's University Hospital, Dublin 4, Ireland. ${ }^{2}$ School of Medicine, University College Dublin, Dublin 4, Ireland. ${ }^{3}$ Hôpital Saint-Louis, Centre National de Référence des Histiocytoses, Service de Pneumologie, Assistance Publique-Hôpitaux de Paris, Paris, France. ${ }^{4}$ Hôpital Européen Georges Pompidou, Service de Biochimie, Assistance PubliqueHôpitaux de Paris, Paris, France. ${ }^{5}$ Université de Paris, INSERM U976, Institut de Recherche Saint-Louis, 75006 Paris, France. ${ }^{6}$ Centre National de Référence des Histiocytoses, Service de Pneumologie, Hôpital Saint-Louis, 1 Avenue Claude Vellefaux, 75475 Paris Cedex 10, France.

\section{Received: 21 Auqust 2020 Accepted: 1 February 2021}

Published online: 09 February 2021

\section{References}

1. Vassallo R, Harari S, Tazi A. Current understanding and management of pulmonary Langerhans cell histiocytosis. Thorax. 2017;72:937-45.

2. Tazi A, et al. The natural history of adult pulmonary Langerhans cell histiocytosis: a prospective multicentre study. Orphanet J Rare Dis. 2015;10:30.

3. Tazi A, et al. Serial computed tomography and lung function testing in pulmonary Langerhans' cell histiocytosis. Eur Respir J. 2012;40:905-12.

4. Liu H, et al. MAPK mutations and cigarette smoke promote the pathogenesis of pulmonary Langerhans cell histiocytosis. JCI Insight. 2020. https://doi.org/10.1172/jci.insight.132048.

5. Liu H, et al. Dendritic Cell Trafficking and Function in Rare Lung Diseases. Am J Respir Cell Mol Biol. 2017;57:393-402.
6. Hayashi T, et al. Immunohistochemical study of matrix metalloproteinases and their tissue inhibitors in pulmonary Langerhans' cell granulomatosis. Arch Pathol Lab Med. 1997:121:930-7.

7. Lomas DA, Evans DL, Finch JT, Carrell RW. The mechanism of Z alpha 1-antitrypsin accumulation in the liver. Nature. 1992;357:605-7. https:// doi.org/10.1038/357605a0.

8. Curiel DT, Chytil A, Courtney M, Crystal RG. Serum alpha 1-antitrypsin deficiency associated with the common S-type (Glu264--Val) mutation results from intracellular degradation of alpha 1-antitrypsin prior to secretion. J Biol Chem. 1989;264:10477-86.

9. McCarthy C, Reeves EP, McElvaney NG. The role of neutrophils in alpha-1 antitrypsin deficiency. Ann Am Thorac Soc. 2016;13(Suppl 4):S297-304. https://doi.org/10.1513/AnnalsATS.201509-634KV.

10. Malerba M, et al. Neutrophilic inflammation and IL-8 levels in induced sputum of alpha-1-antitrypsin PiMZ subjects. Thorax. 2006;61:129-33. https://doi.org/10.1136/thx.2005.043471.

11. Bergin DA, et al. alpha-1 Antitrypsin regulates human neutrophil chemotaxis induced by soluble immune complexes and IL-8. J Clin Invest. 2010;120:4236-50. https://doi.org/10.1172/JCl41196.

12. Hinman LM, Stevens CA, Matthay RA, Gee JB. Elastase and lysozyme activities in human alveolar macrophages. Effects of cigarette smoking. Am Rev Respir Dis. 1980;121:263-71. https://doi.org/10.1164/ arrd.1980.121.2.263.

13. Ellis PR, Campbell EJ, Turner AM, Stockley RA. Alpha-1 antitrypsin deficiency: a predisposing factor for the development of pulmonary langerhans cell histiocytosis. Chronic Obstr Pulm Dis. 2019;6:206-9. https ://doi.org/10.15326/jcopdf.6.3.2019.0129.

14. Radzikowska E, Struniawski R, Chorostowska-Wynimko J, Wiatr E, Roszkowski-Sliz K. Pulmonary langerhans cell histiocytosis - insight into the incidence of alfa-1-antitrypsin (A1ATD) deficiency alleles. Adv Respir Med. 2017;85:297-300. https://doi.org/10.5603/ARM.2017.0051.

15. Donato LJ, Jenkins SM, Smith C, Katzmann JA, Snyder MR. Reference and interpretive ranges for alpha(1)-antitrypsin quantitation by phenotype in adult and pediatric populations. Am J Clin Pathol. 2012;138:398-405. https://doi.org/10.1309/AJCPMEEJK32ACYFP.

16. Zerimech $F$, et al. Evaluation of a new Sebia isoelectrofocusing kit for alpha 1-antitrypsin phenotyping with the Hydrasys System. Clin Chem Lab Med. 2008;46:260-3. https://doi.org/10.1515/CCLM.2008.036.

17. Blanco I, de Serres FJ, Fernandez-Bustillo E, Lara B, Miravitlles M. Estimated numbers and prevalence of $\mathrm{Pl}{ }^{*} \mathrm{~S}$ and $\mathrm{Pl}{ }^{*} \mathrm{Z}$ alleles of alpha1-antitrypsin deficiency in European countries. Eur Respir J. 2006;27:77-84. https://doi. org/10.1183/09031936.06.00062305.

\section{Publisher's Note}

Springer Nature remains neutral with regard to jurisdictional claims in published maps and institutional affiliations.

Ready to submit your research? Choose BMC and benefit from

- fast, convenient online submission

- thorough peer review by experienced researchers in your field

- rapid publication on acceptance

- support for research data, including large and complex data types

- gold Open Access which fosters wider collaboration and increased citations

- maximum visibility for your research: over 100M website views per year

At BMC, research is always in progress.

Learn more biomedcentral.com/submissions 